\title{
Evidence suggesting that the elevated plasma triiodothyronine concentration of rats fed on protein deficient diets is physiologically active
}

\author{
BY ANA LYDIA SAWAYA AND P. G. LUNN \\ Dunn Nutritional Laboratory, Downham's Lane, Milton Road, Cambridge CB4 $1 X J$
}

(Received 10 February 1984 - Accepted 17 August 1984)

1. Some metabolic indicators of thyroid hormone activity have been investigated in rats fed on either protein-deficient or energy-restricted diets.

2. Rats were divided into three groups. Control animals were maintained on a diet of protein energy : total energy (P:E) value of 0.20, while the low-protein group (LP) were allowed ad lib. access to food of P:E 0.03. Energy-restricted (ER) rats were given limited amounts of a control diet $(P: E$ 0.20) such that their rate of growth matched that of LP animals.

3. Animals fed on the LP diet had elevated plasma concentrations of both total and free triiodothyronine $\left(\mathrm{T}_{3}\right)$ concentrations whereas those on the ER regimen showed values below those of controls.

4. The activities of mitochondrial $\alpha$-glycerol-3-phosphate dehydrogenase $(E C 1.1 .99 .5)$ and of the $\alpha$-glycerol3-phosphate shuttle system were elevated in the liver of LP rats, but malate-aspartate shuttle operation was reduced. All three activities were reduced in ER animals.

5. Cytochrome $c$ oxidase (EC 1.9.3.1) activity of brown adipose tissue indicated a high rate of thermogenic activity in this tissue in LP rats, but ER animals showed some evidence of below normal function.

6. The results indicate that both the raised plasma $T_{3}$ of LP rats and the reduced levels observed in ER animals are physiologically significant.

Recent work (Lunn \& Austin, $1983 a, b$ ) has indicated that the hypoalbuminaemia seen in rats given less than optimum levels of protein develops as a consequence of the animal's metabolic response to its relative excess energy consumption rather than to protein deficiency per se. Raised plasma concentrations of (total) triiodothyronine $\left(T_{3}\right)$ were also demonstrated in such rats and the values shown to be directly related to energy consumption but inversely correlated with plasma albumin concentration. These results invite the suggestion that $T_{3}$ itself may be involved in the mechanism by which excess dietary energy can result in the appearance of hypoalbuminaemia in animals fed on protein-deficient diets.

However, although it is generally accepted that rats fed on diets of low protein content do have elevated plasma $T_{3}$ concentrations, there is disagreement as to whether or not the raised levels are metabolically active. Both Cox et al (1980) and Smallridge et al. (1982) have reported the plasma concentration of free $T_{3}$ to be either normal or reduced in low-protein-fed rats and consequently suggest that, despite the raised total $T_{3}$ value, thyroid-induced metabolic action would be unaltered or even reduced. On the other hand, Tulp et al. (1979), Tyzbir et al. (1981) and Rothwell et al. (1983) recorded increased basal metabolic rates and other biochemical evidences of raised thyroid hormone activity in their protein-deficient rats.

It is possible that the metabolic capability of rats to consume and dissipate excess energy may vary widely between strains and housing conditions in much the same way as cafeteria-feeding-induced thermogenesis appears to do. In previous publications from this laboratory in which the relationship between diet, hypoalbuminaemia and thyroid hormones have been investigated (Lunn \& Austin, 1983a,b), it has been assumed that the animals were hyperthyroid, but as there is clearly controversy on this subject it is important that the true thyroid status of the animals be determined. In the present investigation, therefore, we report on the activity of some thyroid-hormone-sensitive enzymes in the liver and also the oxidative 
capacity of brown adipose tissue (BAT) observed when rats of the strain used at the Dunn Nutritional Laboratory are fed on a diet of low-protein energy:total energy (P:E) value, and in energy-restricted (ER) animals growing at the same rate as the low-protein-fed (LP) rats.

\section{MATERIALS AND METHODS}

Males from an inbred, specific-pathogen-free strain of hooded rats maintained at the Dunn Nutritional Laboratory were used in the experiment. The eighteen animals were weaned at 3 weeks on to a synthetic, casein-based diet of P:E $0 \cdot 20$, supplemented with cystine (Lunn et al. 1976). After $7 \mathrm{~d}$ the animals were divided into three groups of six. Rats in the control (C) group continued to receive the P:E 0.20 diet ad lib., but those in the LP group were fed $a d l i b$. a diet of $P: E$ 0.03. An ER group were also given the P:E 0.20 diet but this was restricted such that growth rates of these animals were similar to those of the LP rats. The daily food allowance was given as a single feed in the late afternoon.

These dietary treatments were continued for 2 weeks during which animals were weighed and their food consumption recorded daily. The rats were individually housed in wire cages fitted with trays to collect food spillage. Ambient temperature was between 20 and $25^{\circ}$ and animals were kept on a $12 \mathrm{~h}$ light $-12 \mathrm{~h}$ dark cycle. Water was freely available.

The animals were killed between 10.00 and 11.00 hours by exsanguination under diethyl ether anaesthesia. Blood was collected into heparinized tubes and the resulting plasma stored at $-20^{\circ}$ until required for analysis.

The liver was rapidly removed into ice-cold SHE buffer $(0 \cdot 1 \mathrm{M}$-Hepes, $0 \cdot 1 \mathrm{M}$-dipotassium EDTA, 0.25 M-sucrose, $\mathrm{pH} 7 \cdot 2$ ), blotted and weighed. To prepare liver mitochondria, $1 \mathrm{~g}$ liver was homogenized in $10 \mathrm{ml}$ SHE buffer using a glass tube fitted with a Teflon pestle. For each sample, $500 \mu 1$ homogenate was retained to allow an estimation of mitochondrial recovery and the remainder fractionated by differential centrifugation according to the method of Johnson \& Lardy (1967).

Interscapular BAT was removed into ice-cold SHE buffer and separated from adhering muscle and white fat. It was then blotted, weighed and homogenized as described for liver tissue. All operations were performed below $4^{\circ}$.

\section{Enzyme assays}

Cytochrome $c$ oxidase ( $E C$ 1.9.3.1) was assayed in liver and brown fat homogenates and liver mitochondria by following the oxidation of reduced cytochrome $c$ spectrophotometrically at $550 \mathrm{~nm}$ according to the method of Yonetani \& Ray (1965). The difference between the activity of this enzyme in liver homogenates and the corresponding isolated mitochondria was used as an index of mitochondrial recovery. In this experiment an average value of 71.4 (SE 3.8$) \%$ was obtained. Values obtained for other mitochondrial enzymes were corrected for recovery to enable assessments of total organ activity to be made.

An assay for liver mitochondrial $\alpha$-glycerol-3-phosphate dehydrogenase (EC 1 l 1 l 99 . 5 ., M- $\alpha$-GPD) was performed using phenazine methosulphate (PMS) and 2-p-iodophenyl3-p-nitrophenyl-5-phenylmonotetrazolium chloride (INT) as electron acceptors, following the method of Lamartiniere \& Weiss (1974).

The activities of the $\alpha$-glycerol-3-phosphate ( $\alpha$-GP) and malate-aspartate (M-A) shuttle systems were measured in liver mitochondria according to Tyzbir et al. (1981). Blanks were obtained by adding to the mitochondrial preparation all the extra-mitochondrial components of the system except the enzymes, i.e. $\alpha$-glycerol-3-phosphate dehydrogenase (NAD ${ }^{+}$) $(E C 1.1 .1 .8)$ for the $\alpha$-GP shuttle, and aspartate aminotransferase (EC 2.6.1.1) and malate dehydrogenase ( $E C$ 1.1.1.37) for the $\mathrm{M}-\mathrm{A}$ system. Reagents and enzymes were all obtained from Sigma, London. 
Table 1. Body-weight, food consumption and plasma constituents of rats fed on control $(C)$, low-protein $(L P)$, or energy-restricted $(E R)$ diets $\dagger$

(Mean values with their standard errors)

\begin{tabular}{|c|c|c|c|c|c|c|}
\hline \multirow[t]{2}{*}{ Dietary group... } & \multicolumn{2}{|l|}{$\mathrm{C}$} & \multicolumn{2}{|l|}{ ER } & \multicolumn{2}{|l|}{ LP } \\
\hline & Mean & SE & Mean & $\mathrm{SE}$ & Mean & $\mathrm{SE}$ \\
\hline Final body-wt (g) & 201 & 7 & $138^{* * *}$ & 3 & $131^{* * *}$ & 6 \\
\hline $\begin{array}{l}\text { Food consumption } \\
\text { (g/d per kg body-wt) }\end{array}$ & $119 \cdot 0$ & $3 \cdot 2$ & $67 \cdot 5 * * *$ & $1 \cdot 6$ & $105 \cdot 5^{* *}$ & $3 \cdot 3$ \\
\hline Plasma albumin $(\mathrm{mg} / \mathrm{ml})$ & $31 \cdot 1$ & $0 \cdot 3$ & $32 \cdot 0$ & $0 \cdot 3$ & $26 \cdot 1^{* *}$ & 0.5 \\
\hline Plasma insulin $(\mu \mathrm{U} / \mathrm{ml})$ & 164 & 45 & $54^{*}$ & 5 & $52^{*}$ & 5 \\
\hline Plasma total $T_{3}(\mathrm{ng} / \mathrm{ml})$ & $1 \cdot 15$ & 0.07 & $0.81^{* * *}$ & 0.03 & $1 \cdot 54^{*}$ & 0.09 \\
\hline Plasma free $T_{3}(\mathrm{pg} / \mathrm{ml})$ & 0.98 & $0 \cdot 11$ & $0.42^{* * *}$ & $0 \cdot 13$ & $1 \cdot 80^{* * *}$ & 0.26 \\
\hline
\end{tabular}

$T_{3}$, triiodothyronine.

Values were statistically significantly different from group $\mathrm{C}:{ }^{*} P<0.05,{ }^{* *} P<0.01,{ }^{* * *} P<0.001$.

$\dagger$ For details, see p. 176.

Table 2. Liver weight and mitochondrial protein content of rats fed on control $(C)$, low-protein $(L P)$ or energy-restricted $(E R)$ diets $\dagger$

(Mean values with their standard errors)

\begin{tabular}{|c|c|c|c|c|c|c|}
\hline \multirow[t]{2}{*}{ Dietary group... } & \multicolumn{2}{|c|}{$\mathrm{C}$} & \multicolumn{2}{|c|}{ ER } & \multicolumn{2}{|c|}{ LP } \\
\hline & Mean & $\mathrm{SE}$ & Mean & SE & Mean & $\mathbf{S E}$ \\
\hline Liver wt (g) & $10 \cdot 44$ & 0.46 & $6 \cdot 27^{* * *}$ & 0.15 & $6 \cdot 14^{* * *}$ & 0.37 \\
\hline Liver wt (g/kg body-wt) & $52 \cdot 0$ & 1.0 & $46 \cdot 8^{* *}$ & 1.2 & $45 \cdot 6^{* * *}$ & 0.7 \\
\hline \multicolumn{7}{|c|}{ Hepatic mitochondrial protein } \\
\hline $\mathrm{mg} / \mathrm{g}$ liver & $27 \cdot 6$ & 0.08 & $30 \cdot 5$ & $1 \cdot 2$ & $24 \cdot 1$ & $1 \cdot 2$ \\
\hline $\mathrm{mg} /$ total liver & 288.8 & $15 \cdot 9$ & $190 \cdot 6 * * *$ & $5 \cdot 1$ & $146 \cdot 9 * * *$ & $9 \cdot 5$ \\
\hline Total $\mathrm{mg} / \mathrm{kg}$ body-wt & 1436 & 45 & 1388 & 47 & $1120^{* * *}$ & 39 \\
\hline
\end{tabular}

Values were statistically significantly different from group $\mathrm{C}:{ }^{* *} P<0 \cdot 01,{ }^{* * *} P<0 \cdot 001$.

$\dagger$ For details, see p. 176.

Protein content of the tissues was assessed with a Biuret reagent and plasma albumin was determined using a bromocresol-green technique. These two determinations and all the enzyme assays were performed using a Cobas Bio centrifugal analyser (Roche, Basel). This machine allowed the volumes of reagents and samples to be reduced tenfold compared with the published assays, but methods were not otherwise modified.

Plasma concentrations of insulin and triiodothyronine $\left(T_{3}\right)$ were measured by radioimmunoassay using reagents supplied in kit form by Amersham International plc (Amersham, Bucks). Plasma free $\mathrm{T}_{3}$ was measured with a solid phase RIA kit obtained from Diagnostic Products (UK) Ltd, Wallingford, Oxon. Statistical differences were assessed using Student's $t$ test.

\section{RESULTS}

It is clear from the final body-weights shown in Table 1, that dietary restriction of both protein or total food resulted in a marked reduction in growth performance. As intended, however, body-weights and thus growth of rats in the two malnourished groups had been 
Table 3. Hepatic enzyme and shuttle activities in rats fed on control $(C)$, low-protein (LP) or energy-restricted ( $E R)$ diets $\ddagger$

(Mean values with their standard errors)

\begin{tabular}{|c|c|c|c|c|c|c|}
\hline \multirow[b]{2}{*}{ Dietary group } & \multicolumn{2}{|c|}{$\mathrm{C}$} & \multicolumn{2}{|l|}{ ER } & \multicolumn{2}{|l|}{ LP } \\
\hline & Mean & SE & Mean & SE & Mean & $\mathrm{SE}$ \\
\hline \multicolumn{7}{|c|}{$\begin{array}{l}\text { Mitochondrial } \alpha \text {-glycerol-3-phosphate } \\
\text { dehydrogenase }(E C 1.1 .99 .5) \xi\end{array}$} \\
\hline $\mathrm{U} / \mathrm{g}$ liver & $1 \cdot 23$ & $0 \cdot 04$ & $0 \cdot 96^{* *}$ & $0 \cdot 04$ & $2 \cdot 19^{* *++\dagger}$ & $0 \cdot 22$ \\
\hline U/total liver & $12 \cdot 86$ & 0.78 & $5 \cdot 99 * *$ & 0.28 & $13.39+t+$ & 1.24 \\
\hline $\begin{array}{l}\text { Total U/liver per } \mathrm{kg} \\
\text { body-wt }\end{array}$ & $63 \cdot 8$ & 1.8 & $43 \cdot 7^{* * *}$ & $2 \cdot 5$ & $102 \cdot 2^{* *+1+\dagger}$ & 8.9 \\
\hline $\begin{array}{l}\mathrm{mU} / \mathrm{mg} \text { mitochondrial } \\
\text { protein }\end{array}$ & $44 \cdot 64$ & 1.60 & $31 \cdot 63^{* * *}$ & 1.82 & $91 \cdot 08^{* * *}$ & $7 \cdot 08$ \\
\hline \multicolumn{7}{|c|}{$\alpha$-Glycerol-3-phosphate shuttle\|: } \\
\hline $\mathrm{mU} / \mathrm{g}$ liver & 79.9 & 13.9 & $76 \cdot 8$ & $9 \cdot 2$ & $140 \cdot 4^{* *+1 \dagger}$ & 6.9 \\
\hline $\mathrm{mU} / \mathrm{g}$ per total liver & 861.8 & $115 \cdot 2$ & $436 \cdot 3^{* *}$ & $31 \cdot 7$ & $930 \cdot 0+t^{\dagger}$ & $44 \cdot 3$ \\
\hline $\begin{array}{l}\text { Total mU/liver per } \\
\mathrm{kg} \text { body-wt }\end{array}$ & 4152 & 576 & $3214^{* * *} \quad 2$ & 239 & $6563^{* * \dagger \dagger \dagger}$ & 66 \\
\hline $\begin{array}{l}\mathrm{mU} / \mathrm{mg} \text { mitochondrial } \\
\text { protein }\end{array}$ & 2.79 & 0.45 & $2 \cdot 48$ & $0 \cdot 38$ & $5 \cdot 90 * * *+\dagger \dagger$ & +0.28 \\
\hline \multicolumn{7}{|l|}{ Malate-aspartate shuttle $\|:$} \\
\hline $\mathrm{U} / \mathrm{g}$ liver & $2 \cdot 12$ & $0 \cdot 15$ & $1 \cdot 56^{* *}$ & 0.08 & $1 \cdot 24 * * * \dagger \dagger$ & 0.06 \\
\hline U/total liver & 21.92 & 1.23 & $10 \cdot 10^{* * *}$ & 0.71 & $7 \cdot 50^{* * *+\dagger}$ & $0 \cdot 10$ \\
\hline $\begin{array}{l}\text { Total U/liver per } \\
\mathrm{kg} \text { body-wt }\end{array}$ & $110 \cdot 0$ & 7.8 & $73 \cdot 3^{* *}$ & $4 \cdot 7$ & $57 \cdot 7 * * *+\dagger$ & 1.8 \\
\hline $\begin{array}{l}\mathrm{mU} / \mathrm{mg} \text { mitochondrial } \\
\text { protein }\end{array}$ & $77 \cdot 0$ & $6 \cdot 3$ & $51 \cdot 7^{* *}$ & $4 \cdot 2$ & $51 \cdot 8^{* *}$ & $2 \cdot 6$ \\
\hline \multicolumn{7}{|c|}{ Cytochrome $c$ oxidase $(E C 1.9 .3 .1) \uparrow$} \\
\hline $\mathrm{U} / \mathrm{g}$ liver & 61.9 & $2 \cdot 7$ & $95 \cdot 7^{* * *}$ & $3 \cdot 2$ & $34 \cdot 4^{* * *+\dagger \dagger}$ & 2.6 \\
\hline U/total liver & 646.8 & $41 \cdot 0$ & $601 \cdot 7$ & $32 \cdot 6$ & $212 \cdot 7^{* * *+1+\dagger}$ & $21 \cdot 3$ \\
\hline $\begin{array}{l}\text { Total U/liver per } \mathrm{kg} \\
\text { body-wt }\end{array}$ & 3321 & 171 & $4360^{* * *}$ & 164 & $1607^{* * *+\dagger \dagger}$ & 116 \\
\hline $\begin{array}{l}\mathrm{U} / \mathrm{mg} \text { mitochondrial } \\
\text { protein }\end{array}$ & $2 \cdot 21$ & 0.09 & $3 \cdot 19 * * *$ & $0 \cdot 18$ & $1.45^{* * *+1+\dagger}$ & $\dagger 0 \cdot 13$ \\
\hline
\end{tabular}

Values were statistically significantly different from group $\mathrm{C}: * * P<0 \cdot 01, * * * P<0.001$.

Values were statistically significantly different from group ER: $\dagger \dagger P<0.01 \dagger \dagger \dagger P<0.001$.

$\$$ For details, see p. 176.

$\S \alpha$-Glycerol-3-phosphate dehydrogenase activity was expressed as $\mu \mathrm{mol}$ formazan formed/min (molar extinction coefficient $1.85 \times 10^{4} / \mathrm{M}$ per $\mathrm{cm}$ at $500 \mathrm{~nm}$ ).

$\|$ Shuttle activities were expressed as $\mu \mathrm{mol}$ NADH oxidized $/ \mathrm{min}$.

Tा Cytochrome $c$ oxidase activity was expressed as $\mu \mathrm{mol}$ reduced cytochrome $c$ oxidized/min.

depressed to a closely similar extent. The food intake of the ER group of animals was approximately $55 \%$ of that eaten by control rats; however, rats fed on the LP diet ate slightly less than controls even when this was expressed on a body-weight basis.

Table 1 also contains the results for the plasma concentrations of albumin, insulin and total and free $T_{3}$ in the three experimental groups. Plasma albumin values of LP rats showed the expected significant hypoalbuminaemia but in the ER group concentrations did not differ from those of control animals. Mean plasma insulin concentrations of both the ER and LP groups were significantly lower than control values, but did not differ from one another. In contrast, both total and free plasma $T_{3}$ values in the two dietary restricted groups varied in opposite directions from control values; LP rats had significantly elevated values whereas in ER animals concentrations were much reduced. 
Table 4. Changes in interscapular brown adipose tissue (BAT) induced by feeding rats on low-protein $(L P)$ or energy-restricted $(E R)$ diets $\dagger$

(Mean values with their standard errors)

\begin{tabular}{|c|c|c|c|c|c|c|}
\hline \multirow[t]{2}{*}{ Dietary group... } & \multicolumn{2}{|c|}{$\mathrm{C}$} & \multicolumn{2}{|c|}{ ER } & \multicolumn{2}{|c|}{ LP } \\
\hline & Mean & $\mathrm{SE}$ & Mean & $\mathrm{SE}$ & Mean & SE \\
\hline BAT wt (mg) & 645 & 54 & $395^{* * *}$ & 20 & 596 & 27 \\
\hline BAT wt (mg/kg body-wt) & 3200 & 190 & 2880 & 180 & $4570^{* * *}$ & 180 \\
\hline BAT protein $(\mathrm{mg})$ & 29.9 & 3 & $13 \cdot 6^{* * *}$ & 0.6 & $25 \cdot 1$ & 3.8 \\
\hline $\begin{array}{l}\text { BAT protein } \\
\text { (mg/kg body-wt) }\end{array}$ & 149 & 13 & $100^{* * *}$ & 3 & 190 & 23 \\
\hline \multicolumn{7}{|l|}{$\begin{array}{l}\text { Cytochrome } c \text { oxidase } \\
(E C 1.9 .3 .1)_{\ddagger}^{+}:\end{array}$} \\
\hline Total U/BAT & $31 \cdot 7$ & $1 \cdot 4$ & $19 \cdot 5^{* * *}$ & 1.0 & $40 \cdot 7^{* *}$ & $2 \cdot 3$ \\
\hline Total $\mathrm{U} / \mathrm{kg}$ body-wt & 160 & 12 & 142 & 9 & $313^{* * *}$ & 16 \\
\hline
\end{tabular}

Values were statistically significantly different from group $C:{ }^{* *} P<0 \cdot 01,{ }^{* * *} P<0 \cdot 001$.

$\dagger$ For details, see p. 176.

$\ddagger$ Cytochrome $c$ oxidase activity was defined as $\mu \mathrm{mol}$ reduced cytochrome $c$ oxidized $/ \mathrm{min}$.

\section{Liver measurements}

In keeping with the body-weight changes, liver weights of ER and LP rats were lower than controls and this difference persisted even when the values were expressed per $\mathrm{kg}$ body-weight (Table 2). Liver weights of animals of the ER and LP groups were similar. No significant differences in hepatic mitochondrial protein content were apparent between controls and dietary restricted animals when the results were expressed per g liver, but LP rats showed lower values when the weight of the liver or the weight of the animal was taken into account. ER rats presented significantly lower mitochondrial protein content only when expressed per total liver.

Marked alterations in the activity of M- $\alpha$-GPD were observed in animals fed on the three different diets (Table 3). The activity of this enzyme was much higher in rats offered the LP diet than it was in the control group but, in contrast, animals on the ER regimen exhibited suppressed activity. This finding is supported by measurements of the activity of the $\alpha$-GP shuttle system in mitochondria from the three groups of rats (Table 3), where the two restricted dietary treatments again elicited marked but opposite changes in activity. LP rats had a much higher activity than controls but ER animals showed a reduction.

Changes in the activity of the M-A shuttle system in response to the dietary treatments were also observed and are shown in Table 3. LP rats exhibited a significant reduction in activity when compared with control animals which contrasts with the increase found in the $\alpha$-GP shuttle. M-A shuttle activity was also reduced in the ER group of rats but in this case values were intermediary between controls and LP animals. There was, however, no difference between the LP and ER groups when shuttle activity was expressed relative to mitochondrial protein, although both were significantly lower than the control value.

Hepatic cytochrome $c$ oxidase activity (Table 3) was higher in ER rats than in controls when expressed either per $\mathrm{g}$ liver, per total liver $/ \mathrm{kg}$ body-weight or per $\mathrm{mg}$ mitochondrial protein. LP rats, in contrast, had lower values when enzyme activity was assessed in these ways. 


\section{$B A T$ measurements}

The weight of interscapular BAT of rats fed on the LP diet was higher, on a body-weight basis, than that of control animals (Table 4). The protein content also tended to be higher than the value obtained from control animals but this difference failed to reach significance. On the other hand, BAT of ER rats weighed only slightly less than controls but contained significantly less protein. An indication of the metabolic activity of this tissue was obtained by estimation of cytochrome $c$ oxidase activity and these results are presented in Table 4 . Total activity per organ was significantly higher in the LP rats compared with controls and when the results were adjusted to correct for body-weight differences, the activity of the enzyme was found to be approximately double that of the control animals. ER rats, although having a lower activity per total BAT, did not differ from controls when body-weight was taken into account.

\section{DISCUSSION}

Rats in the LP and ER groups showed characteristic features of their dietary treatments. Growth was restricted in both groups but hypoalbuminaemia developed only in the LP-fed animals. Although food consumption of LP rats was only slightly lower than that of controls, plasma insulin concentration was much reduced and, in keeping with previous reports (Tulp et al. 1979; Lunn \& Austin, 1983 a), plasma $\mathrm{T}_{3}$ concentrations were elevated. ER rats also exhibited low plasma levels of insulin but, unlike the LP animals, had $T_{3}$ values well below control concentrations.

The alterations observed in the liver enzymes and in BAT oxidative activity of rats fed on the LP diet are in keeping with the suggestion that when offered their food ad lib., these animals consume excess amounts of energy and dispose of most of it by thermogenic mechanisms (Tyzbir et al. 1981, Lunn \& Austin 1983b). Similar measurements made on ER animals in general showed changes which were the reverse of those seen in LP rats and which would tend to improve the efficiency of energy utilization. Thus, despite an overall reduction in organ weight and mitochondrial protein content, the activities of M- $\alpha-\mathrm{GPD}$ and the $\alpha$-GP shuttle system were markedly raised in the liver of the LP rats. On the other hand, the activity of the M-A shuttle was reduced. Similar changes in these indices are known to occur in other situations associated with hyperphagia and raised plasma $\mathrm{T}_{3}$ concentrations, e.g. cafeteria feeding (Rothwell et al. 1982) and cold exposure (Stirling \& Stock, 1968). In contrast, the reduced activities of M- $\alpha$-GPD and the $\alpha$-GP shuttle in the livers of ER rats would tend to improve energy economy. The changes in liver cytochrome $c$ oxidase activity of the dietary restricted animals are in keeping with the general condition of the liver. In LP rats where this organ is poorly maintained in both structure and function (Coward et al. 1977), cytochrome $c$ oxidase activity was reduced by about half but was above control values in ER animals where the liver retained a more normal state.

Assessment of interscapular BAT function by weight, protein content and, in particular, cytochrome $c$ oxidase activity, demonstrates the expected changes in response to the dietary treatments. BAT activity was increased in rats fed on the LP diet, a result clearly supporting suggestions of a high rate of energy dissipation in animals fed on low-protein-diets ad lib. ER animals in contrast showed evidence of a lower than normal BAT activity.

These changes in enzyme activity can all be attributed to the alterations in free $T_{3}$ concentrations seen in the LP and ER animals. M- $\alpha$-GPD has long been known as a specific target enzyme for thyroid hormones, invariably being elevated when plasma values are high and reduced when they are low (Stirling \& Stock, 1968; Gurr et al. 1980; Tyzbir et al., 1981). As this enzyme exerts a major influence on the rate of the $\alpha$-GP shuttle, then this system would be expected to be increased in hyperthyroid states and indeed this is so (Lee \& Lardy, 
1965; Rothwell et al., 1982). On the other hand, although less-well characterized, the M-A shuttle is reduced when normal animals are treated with thyroid hormones (Lamartiniere \& Weiss, 1974). Finally, BAT activity is undoubtedly partially under the control of thyroid hormones. Currently it is thought that $T_{3}$ might influence the number of noradrenaline receptor sites in the tissue and consequently the long term control of tissue activity (Rothwell \& Stock, 1980). Cytochrome $c$ oxidase, although not so sensitive as other indicators of BAT function, does nevertheless give a very good measure of such long-term alterations in oxidative capacity.

A knowledge of the true nature of the thyroid response of our animals to diets of low-protein or low-energy content is essential for a correct interpretation of the relation which has been described between plasma total $\mathrm{T}_{3}$ and albumin (Lunn \& Austin, 1983a,b). If the low-protein diet had resulted in a hypothyroid response, the association with hypoalbuminaemia might have been simply explained. Low levels of thyroid hormones are known to cause a reduction in the synthesis of many liver proteins, including albumin, and this effect is thought to account for the low values of this plasma protein observed in cases of myxoedema (Peavy et al. 1981 a,b). However, all the evidence obtained in the present study is consistent with a hyperthyroid response and thus reinforces the theory that $T_{3}$ may be involved in the generation of hypoalbuminaemia via 'dysadaptation' as described previously (Lunn \& Austin, 1983 b). ER animals, on the other hand, maintain normal plasma albumin concentrations, so clearly the marked reduction in thyroid status of these animals is not sufficient to affect synthesis rates so badly that hypoalbuminaemia occurs. Certainly, thyroid hormones exert many and varied effects on nitrogen metabolism, but whether or not they have a direct or indeed indirect influence on the appearance of kwashiorkor-like symptoms remains to be elucidated.

Why different groups investigating the response of animals to low-protein diets should obtain different results remains an unanswered question. It can only be assumed that variations between animal strains, age, diets, housing and feeding conditions and particularly environmental temperature, have a far greater impact on the animals' response to altered diets than has generally been realized.

\section{REFERENCES}

Coward, W. A., Whitehead, R. G. \& Lunn, P. G. (1977). British Journal of Nutrition 38, 115-126.

Cox, M. D., Dalal, S. S. \& Heard, C. P. C. (1980). Proceedings of the Nutrition Society 40, 39 A.

Gurr, M. I., Mawson, R., Rothwell, N. J. \& Stock, M. J. (1980). Journal of Nutrition 110, 532-542.

Johnson, D. \& Lardy, H. (1967). In Methods in Enzymology, vol. 10, pp. 94-96 [R. W. Estabrook, editor]. New York: Academic Press.

Lamartiniere, G. A. \& Weiss, G. (1974). Hoppe-Seyler's Zeitschrift fur Physiologische Chemie 355, $1549-1554$.

Lee, Y. P. \& Lardy, H. A. (1965). Journal of Biological Chemistry 240, 1427-1436.

Lunn, P. G. \& Austin, S. (1983a). Journal of Nutrition 113, 1791-1802.

Lunn, P. G. \& Austin, S. (1983 b). British Journal of Nutrition 49, 9-15.

Lunn, P.G., Whitehead, R.G. \& Baker, B.A. (1976). British Journal of Nutrition 36, 219-230.

Peavy, D. E., Taylor, J. M. \& Jefferson, L. S. (1981 a). American Journal of Physiology 240, E18-E23.

Peavy, D. E., Taylor, J. M. \& Jefferson, L. S. (1981 b). Biochemical Journal 198, 289-299.

Rothwell, N. J. \& Stock, M. J. (1980). Pflugers Archives 389, 237-272.

Rothwell, N. J., Stock, M. J. \& Tyzbir, R. S. (1982). Journal of Nutrition 112, 1663-1672.

Rothwell, N. J., Stock, M. J. \& Tyzbir, R. S. (1983). Metabolism 32, 257-261.

Smallridge, R. G., Glass, A. R., Wartofsky, L., Latham, K. R. \& Burman, K. D. (1982). Metabolism 31, $538-542$.

Stirling, J. L. \& Stock, M. J. (1968). Nature 220, 801-802.

Tulp, O. L., Krupp, P. P., Danforth, E. Jr \& Horton, E. S. (1979). Journal of Nutrition 109, 1321-1332.

Tyzbir, R. S., Kunin, A. S., Sims, N. M. \& Danforth, E. Jr (1981). Journal of Nutrition 111, 252-259.

Yonetani, T. \& Ray, G. S. (1965). Journal of Biological Chemistry 240, 3392-3398. 